\title{
Antioxidant defence system and oxidative damages in Rice seedlings under heat stress
}

\author{
Muhammad Kazim Ali ${ }^{1,2 *}$, Abid Azhar ${ }^{1}$, Haneef Ur Rehman ${ }^{3}$ and Saddia \\ Galani $^{1}$ \\ 1. Karachi Institute of Biotechnology and Genetic Engineering (KIBGE), University of Karachi, Karachi-Pakistan \\ 2. Department of Biotechnology, Federal Urdu University of Arts, Science and Technology (FUUAST) Karachi, \\ Karachi-Pakistan \\ 3. Department of Chemistry, University of Turbat, Kech, Balochistan-Pakistan \\ *Corresponding author's email: ali.kazimm@gmail.com
}

Citation

Muhammad Kazim Ali, Abid Azhar, Haneef Ur Rehman and Saddia Galani. Antioxidant defence system and oxidative damages in Rice seedlings under heat stress. Pure and Applied Biology. Vol. 5, Issue 4, pp1131-1141. http://dx.doi.org/10.19045/bspab.2016.50136

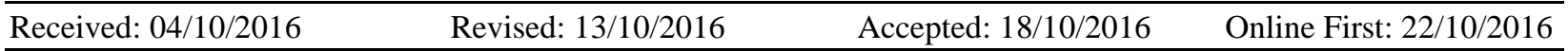

\section{Abstract}

Impact of climate change showed heat stress most severely affecting crop growth and yield worldwide. In current study, oxidative damages and response of antioxidant enzymes were compared in 4 rice cultivars (IR-6, IR-8, K-95 and Sada Hayat). These varieties were exposed to heat $\left(42 \pm 2{ }^{\circ} \mathrm{C}\right)$ stress at seedling stage. After $72 \mathrm{~h}$, stressed plants transferred to normal temperature for recovery treatments. Oxidative stress damages were quantified through analysis of hydrogen peroxide $\left(\mathrm{H}_{2} \mathrm{O}_{2}\right)$ and malondialdehyde (MDA) content. Effect of heat stress on antioxidant enzymes activities were determined by quantitative analysis of ascorbate peroxidase (APX) and catalase (CAT) enzymes. With increasing oxidative stress significant proline accumulation was detected in rice cultivars and K-95 had maximum proline among the group. Significant increment of MDA and hydrogen peroxide $\left(\mathrm{H}_{2} \mathrm{O}_{2}\right)$ content was found in as compared to others. CAT and APX showed significantly declined activity in Sada Hayat and IR-8 under heat stress condition however K-95 showed maximum activity. These findings suggesting that (i) K-95 is comparatively thermotolerant cultivar (ii) thermo-tolerance in rice is closely related to efficient antioxidant enzyme defence system.

Keywords: Oxidative stress; Antioxidants; Lipid peroxidation; Thermotolerance Rice; Enzymes Introduction

Abiotic and biotic stresses are major challenges for sustainable agriculture that posing severe threat to maximum yield through limiting plant growth and development [1]. Specifically, abiotic stress is the primary cause of crop yield loss worldwide [2]. Yield of major economically important crops like wheat, maize and rice are affected by heat stress [3]. It is reported that for a $1{ }^{\circ} \mathrm{C}$ increase in daily mean temperature from threshold nearly $10 \%$ rice yield decreased [4]. Some specific effects are reported for each stress factor on plants but oxidative stress is common in all stress conditions due to over production and accumulation of reactive oxygen species (ROS). Over production of ROS are 
considered as deleterious and lethal to living systems because these are responsible of carbohydrates, lipids, proteins and deoxyribonucleic acid peroxidation leading cell necrosis. Consequently, higher level of free radicles causes a cellular oxidation though a chain reaction. In addition to the oxidative stress related production [5]. Plants have developed an antioxidant defence system and they play key role in detoxifying and balancing ROS in cell [6]. Enzymatic antioxidants including superoxide dismutase (SOD), ascorbate peroxidase (APX), catalase (CAT) and peroxidase (POX) [7, 8]. Among these antioxidant enzymes, SOD is considered as first defence line because it detoxifies superoxide which is the first reactive oxygen species, generate in cell during stress condition [9]. DNA, Protein and lipids are at high risk due to increased production and accumulation of free radicals under oxidative stress [10, 11]. Prolonged exposure to high temperature during sensitive growth stage of plant may lead to leaf senescence, wilting, damages to leaf margins, desiccation, stunted growth, interrupted reproductive development and death of plant [12]. Accumulation of osmolytes (proline) in addition to antioxidant enzymatic scavenging system is another important adaptive strategies of plant to cope with unfavorable environmental conditions. Free proline accumulation is closely related with plant thermal stress tolerance significantly in crops and other plants under stress condition specifically under oxidative stress $[13,14$, 15, 16]. High concentrations of proline can accumulate in plant cells as an osmoprotectant without disrupting cell metabolism and cellular structure in plants subjected to heat stress conditions. Hence, under thermal stress condition, osmotic adjustment, membrane integrity and detoxification of ROS is significantly correlated with proline accumulation in plants $[17,18,19]$.

Under heat stress conditions response of rice investigation at biochemical basis are rare and antioxidative defence mechanisms performance are hardly studied specifically indica rice. Previous investigations on rice response to environmental harsh conditions are mostly focus on the drought stress and salt stress effects on rice and other species of the family. Effect of elevated temperature is rarely studied and some consequences of heat stress at field condition was reported only in rice yield. Although there are many rice cultivars currently sowing in Pakistan but in Sindh province non-aromatic rice mostly used because it experiences warmer summer as compare to other regions. There are no such studies reported before to screen local rice cultivars for thermotolerance. This research is designed in order to determine antioxidant enzyme activities, lipid membrane peroxidation and proline accumulation heat stressed rice seedlings. Molecular mechanisms of thermotolerance is still enigmatic in rice therefore to help in identify thermo-tolerance mechanisms, comparison of different rice cultivars responses towards heat stress will allowing further insights into the heat induced oxidative stress.

\section{Materials and methods \\ Plant materials, growth conditions, and stress treatments}

The seeds of rice (Oryza sativa L.) cultivars (IR-6, IR-8, K-95 and Sada Hayat) were collected from Rice Research Institute, Dokri, (Pakistan). After surface sterilization, rice seeds were allowed to germinate in pots. Seedlings grown in a controlled growth chamber $\left(28 \pm 2{ }^{\circ} \mathrm{C}\right)$ with $16 \mathrm{~h}$ light $(400$

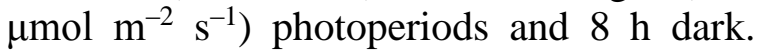
For irrigation Hoagland's solution (half strength) was used [20]. Then plants (20day-old seedlings), growing under normal temperature was considered as control (C), 
were subjected to heat stress (HS) by gradually increasing the temperature and maintained at $42 \pm 2{ }^{\circ} \mathrm{C}$. Sampling were carried out after 24,48 and $72 \mathrm{~h}$ of heat stress. After $72 \mathrm{~h}$, stressed plants transferred to normal $\left(28 \pm 2{ }^{\circ} \mathrm{C}\right)$ temperature for recovery treatments (RC). For control treatment, rice seedlings allowed to grow in the same way and watered with properly in addition of Hoagland's solution supplement. Before investigation of physiological attributes, seedlings were harvested, shoot lengths, fresh and dry weights of shoots were observed. Analysis of MDA and hydrogen peroxide content were determined followed by total quantification of catalase (CAT) and ascorbate peroxidase (APX) enzymes.

\section{Growth parameters}

To show that heat stress effects on rice growth visually, total shoot lengths were recorded followed by photography of samples. Fresh shoot and dry weights were measured as weight of shoot tissue. Shoot and root samples were taken from rice seedlings treated with control, heat stress and recovery conditions, for analysis of fresh weight (FW) at 30 days of rice growth. For dry weights (DW) analysis rice seedling samples were kept in oven at $60{ }^{\circ} \mathrm{C}$ for $24 \mathrm{~h}$.

\section{Hydrogen peroxide $\left(\mathrm{H}_{2} \mathrm{O}_{2}\right)$ content determination}

The production level of $\mathrm{H}_{2} \mathrm{O}_{2}$ was measured spectrophotometrically according to Jessup [21]. $\mathrm{H}_{2} \mathrm{O}_{2}$ was extracted by homogenizing $0.1 \mathrm{~g}$ fresh leaves in $1 \mathrm{ml}$ of $0.1 \%$ TCA. The homogenate was centrifuged at $12000 \mathrm{rpm}$ for 15 minutes. To quantify $\mathrm{H}_{2} \mathrm{O}_{2}$ concentration, $0.5 \mathrm{ml}$ of potassium phosphate $(10 \mathrm{mM})$ and $1 \mathrm{ml}$ of potassium iodide (1M) was mixed with supernatant. Supernatant yellow color intensity was measured $390 \mathrm{~nm}$ using UVspectrophotometer. Extinction coefficient $\left(0.28 \mu\right.$ mole $\left.^{1}{ }^{-} \mathrm{cm}^{-1}\right)$ was used to calculate concentration of $\mathrm{H}_{2} \mathrm{O}_{2}$ in controlled and heat stressed rice seedlings and expressed as $\mu$ mole $\mathrm{g}^{1} \mathrm{FW}$.

\section{Determination of malondialdehyde (MDA) content}

Strength of lipid peroxidation was measured by quantification of total melondialdehyde (MDA) content generated by heat stress treatments for the evaluation of cell membrane damages, according to Ohkawa [22]. Leaf tissues $(0.1 \mathrm{~g})$ was homogenized in $1 \mathrm{ml}$ of $5 \%$ trichloroacetic acid (TCA). The homogenates subjected was then centrifugation for 15 at $12,000 \mathrm{rpm}$. Supernatant was mixed with freshly prepared thiobarbituric acid (TBA, $0.5 \%$ ) in tricholoroacitic acid (TCA, 20\%) and incubated for $30 \mathrm{~min}$ at $95{ }^{\circ} \mathrm{C}$ into new eppendorf tube followed by centrifugation at $10,000 \mathrm{rpm}$. Correction for un-specific turbidity during measurement of MDA content was performed by subtracting the absorbance of $600 \mathrm{~nm}$ and absorbance of $532 \mathrm{~nm}$. Results were expressed in terms of nmol MDA $\mathrm{g}^{-1} \mathrm{FW}$ after calculation of MDA contents using extinction coefficient $\left(155 \mathrm{mM}^{-1} \mathrm{~cm}^{-1}\right)$.

\section{Proline content determination}

Bates [23] method was used for analysis of amount of free proline. For this purpose, 0.1 $\mathrm{g}$ leaf tissue was homogenized in $3 \%$ sulphosalicyclic acid followed by centrifugation at $1200 \mathrm{rpm}$ for 10 minutes. Homogenized tissue $(1 \mathrm{ml})$ was incubated with acid ninhydrin $(2 \mathrm{ml})$ and glacial acetic acid $(1 \mathrm{ml})$ in a test tube incubated for $1 \mathrm{~h}$ at $100{ }^{\circ} \mathrm{C}$. The reaction was stop by place the sample on ice. Toluene $(2 \mathrm{ml})$ was used to extract the reaction mixture by mixed vigorously followed by incubation at room temperature $(30 \mathrm{~min})$ until two phase separation was observed. The chromospheres (upper phase) was used to quantify free proline at $520 \mathrm{~nm}$ using toluene for a blank. 


\section{Determination of enzyme activities}

For antioxidant enzyme analysis, leaf samples were homogenized followed by centrifugation at 13,000 rpm. Supernatant of each sample were used for enzyme activity measurements after centrifugation $(20 \mathrm{~min})$ of homogenate at $12,000 \mathrm{~g}$ at $4{ }^{\circ} \mathrm{C}$. Bradford method [24] was used to determine total protein concentration in leaf extracts Bovine serum albumin (BSA) was used as standard.

Ascorbate peroxidase (APX) enzyme quantification was carried out according to Wang [25] protocol. Suspension solution (1 $\mathrm{ml}$ ) having Tris- $\mathrm{HCl}(\mathrm{pH} 7.2,50 \mathrm{mM}), \mathrm{PVP}$ $(2 \%)$, EDTA $(1 \mathrm{mM})$ and $2 \mathrm{mM}$ of ascorbate mixed with samples containing $100 \mu \mathrm{g}$ of protein. For initiation of the reaction, assay medium was mixed with potassium phosphate buffer (50 mM, pH 6.6), ascorbate $(0.25 \mathrm{mM})$ and $\mathrm{H}_{2} \mathrm{O}_{2}(1 \mathrm{mM})$. The absorbance of ascorbate was measured at $290 \mathrm{~nm}$ for 90s. 1 unit of APX was defined if 0.001 change in absorbance of ascorbate occurred in per minute.

Catalase (CAT) activity was measured by using Chance and Maehly, [26] method. Extracted samples having protein $(100 \mu \mathrm{g})$ were mixed in Tris- $\mathrm{HCl}(1 \mathrm{ml}, 50 \mathrm{mM})$ solution at $\mathrm{pH}$ 7.8. Potassium phosphate (50 Mm, pH 7.0) buffer and $\mathrm{H}_{2} \mathrm{O}_{2}(10 \mathrm{mM})$ was mixed with assay medium. The decline in absorbance of $\mathrm{H}_{2} \mathrm{O}_{2}$ was monitored at 240 $\mathrm{nm}$ for $90 \mathrm{~s}$. 1 unit of CAT was defined as 0.001 change in hydrogen peroxide absorbance per minute.

\section{Data analysis}

All analyses were done using a completely randomized design with 4 replicates $(n=4)$. All data were subjected to one-way analyses of variance (ANOVA). Duncan's multiple range test was used to separate statistically different means at $p<0.01$ and $p<0.05$.

\section{Results and discussion}

Growth parameters

Result analysis revealed that with increase in intensity of heat stress treatment, fresh weights of shoots of all rice cultivars decreased but difference in degree of decline in shoot weight observed. Similarly, dry weight of heat treated rice seedling's shoots decreased significantly $(p \leq 0.05)$ in all cultivars with increase in duration of thermal stress while increment found upon recovery treatments (Table 1). Throughout the experiment no significant effect of thermal stress on the shoot length of rice seedlings were observed although plants showed diverse shoot length within the group may be due to difference in metabolic activities, growth regulators and genetic factors.

Table 1. The effect of heat stress treatments on growth parameters of rice (Oryza sativa L.) cultivars

\begin{tabular}{|l|l|l|l|l|l|l|l|l|}
\hline Growth & Cultivar & \multirow{2}{*}{ Control } & \multicolumn{3}{|c|}{ Heat Stress } & \multicolumn{3}{c|}{ Recovery } \\
\cline { 4 - 8 } & & & T24 & T48 & T72 & R24 & R48 & R72 \\
\hline Shoot Length & IR-6 & $15 \pm 1.0$ & $15 \pm 5.4$ & $15 \pm 4.5$ & $14 \pm 0.6$ & $16 \pm 2.1$ & $15 \pm 4.1$ & $16 \pm 3.2$ \\
$(\mathrm{~cm})$ & IR-8 & $16 \pm 3.2$ & $15 \pm 3.4$ & $15 \pm 3.2$ & $16 \pm 0.9$ & $15 \pm 3.2$ & $16 \pm 3.2$ & $16 \pm 1.3$ \\
& K-95 & $18 \pm 0.2$ & $19 \pm 1.2$ & $19 \pm 2.8$ & $18 \pm 1.2$ & $18 \pm 4.3$ & $18 \pm 5.2$ & $18 \pm 1.2$ \\
P $>0.05$ & SDHT & $15 \pm 3.2$ & $13 \pm 7.6$ & $13 \pm 1.6$ & $13 \pm 2.5$ & $13 \pm 5.4$ & $13 \pm 3.5$ & $14 \pm 5.3$ \\
\hline Shoot Fresh & IR-6 & $0.24 \pm 3.7$ & $0.20 \pm 1.3$ & $0.17 \pm 2.3$ & $0.14 \pm 0.1$ & $0.13 \pm 0.3$ & $0.15 \pm 2.1$ & $0.16 \pm 3.1$ \\
Weight (gm) & IR-8 & $0.24 \pm 2.3$ & $0.18 \pm 0.9$ & $0.15 \pm 4.2$ & $0.13 \pm 0.4$ & $0.13 \pm 0.4$ & $0.14 \pm 2.3$ & $0.15 \pm 3.2$ \\
& K-95 & $0.26 \pm 1.4$ & $0.24 \pm 1.2$ & $0.21 \pm 1.2$ & $0.19 \pm 0.7$ & $0.19 \pm 0.6$ & $0.21 \pm 2.1$ & $0.22 \pm 2.3$ \\
P $<0.05$ & SDHT & $0.20 \pm 1.2$ & $0.16 \pm 2.9$ & $0.13 \pm 4.3$ & $0.10 \pm 0.9$ & $0.11 \pm 0.5$ & $0.11 \pm 3.1$ & $0.13 \pm 1.2$ \\
\hline Shoot Dry & IR-6 & $0.10 \pm 0.2$ & $0.09 \pm 2.1$ & $0.08 \pm 2.1$ & $0.06 \pm 2.1$ & $0.06 \pm 0.1$ & $0.06 \pm 1.2$ & $0.07 \pm 0.1$ \\
Weight (gm) & IR-8 & $0.10 \pm 0.1$ & $0.08 \pm 0.8$ & $0.07 \pm 3.1$ & $0.05 \pm 3.2$ & $0.05 \pm 1.3$ & $0.05 \pm 0.7$ & $0.06 \pm 0.3$ \\
& K-95 & $0.12 \pm 0.4$ & $0.11 \pm 1.4$ & $0.10 \pm 2.5$ & $0.09 \pm 4.2$ & $0.09 \pm 0.5$ & $0.10 \pm 0.6$ & $0.12 \pm 0.3$ \\
P $<0.05$ & SDHT & $0.09 \pm 0.5$ & $0.07 \pm 0.5$ & $0.06 \pm 4.2$ & $0.04 \pm 1.2$ & $0.05 \pm 0.6$ & $0.05 \pm 0.5$ & $0.05 \pm 0.1$ \\
\hline
\end{tabular}

Each value represents the mean of 3 replicates $(n=3)$ and standard deviation of mean $( \pm$ SD). Duncan's multiple range test showed significant differences in means $( \pm \mathrm{SD})$ between control and heat-treated plants at $\mathrm{P}<0.05$ 


\section{Hydrogen peroxide, melondialdehyde and proline contents}

$\mathrm{H}_{2} \mathrm{O}_{2}$ is a reactive compound produced due to scavenging of superoxide radicals by superoxide dismutase (SOD) enzyme. Lipid peroxidation and membrane injury is a sign of higher accumulation of $\mathrm{H}_{2} \mathrm{O}_{2}$ leading death of plants and yield loss [27]. Linear grew in content of $\mathrm{H}_{2} \mathrm{O}_{2}$ in all cultivars were observed with increasing level of heat stress condition however maximum $(p \leq 0.01)$ generation and accumulation of $\mathrm{H}_{2} \mathrm{O}_{2}$ content were found in Sada Hayat as compared to others (Figure 1). In the present study, K-95 cultivars presented lowest values of $\mathrm{H}_{2} \mathrm{O}_{2}$ accumulation under thermal stress, indicated that K-95 has efficient free radical quenching system at a cellular level that offered maximum protection against oxidative stress damages.

Oxidative stress leading cytotoxic damage of protein, DNA and lipid observed in plants subjected to environmental stress conditions because reactive oxygen species (ROS) production overcomes antioxidant defence system capacity [28]. MDA quantification in order to figure out level of lipid peroxidation has been considered as a convenient biomarker due to its reaction with thiobarbituric acid (TBA) forming coloured chromogen [29]. Minimal increment in content of MDA was observed in "K-95", seedlings of "Sada Hayat" (Figure 2). The MDA content was found to be significantly highest in Sada Hayat and and lowest in K95. Minimum values of MDA exhibited by K-95 suggest that it has developed an efficient and effective ROS scavenging system and therefore, showed better performance. Compared to control plants, heat treated rice seedlings had increase level of MDA which shows that rise in temperature beyond optimum for growth could cause peroxidation of membrane lipids making cell porous consequently cell sap leakage leading cell shrink and death [30].

In many plant species proline accumulations under stressful conditions has been positively correlated with tolerance mechanism [16]. The cultivars showed significant increment patterns for proline content in shoot tissues in relation to severity of high temperature stress (Figure 3). Other researchers have reported that stress-tolerant cultivars exhibited higher accumulation of free proline opposed to stress-sensitive varieties [31]. The accumulation of free proline under harsh environmental condition as an advantageous mechanism of living system to protect membrane lipids, proteins and key cellular components insuring maintenance of cell homeostasis when relative water content (RWC) decreases [32]. Decrease in RWC with minimum MDA suggest that increased accumulation of proline insuring cell membrane integrity. In various plants (cucumber, sunflower, chickpea and tomato), increase in free proline accumulation have been reported under oxidative stress [33-37], which is considered important adaptive and protection mechanism to cope with consequences of heat stress. In addition of proline measurement, analysis of chlorophyll fluorescence can be carried out in order to elucidate effect of thermal stress on photosynthetic apparatus [38]. 


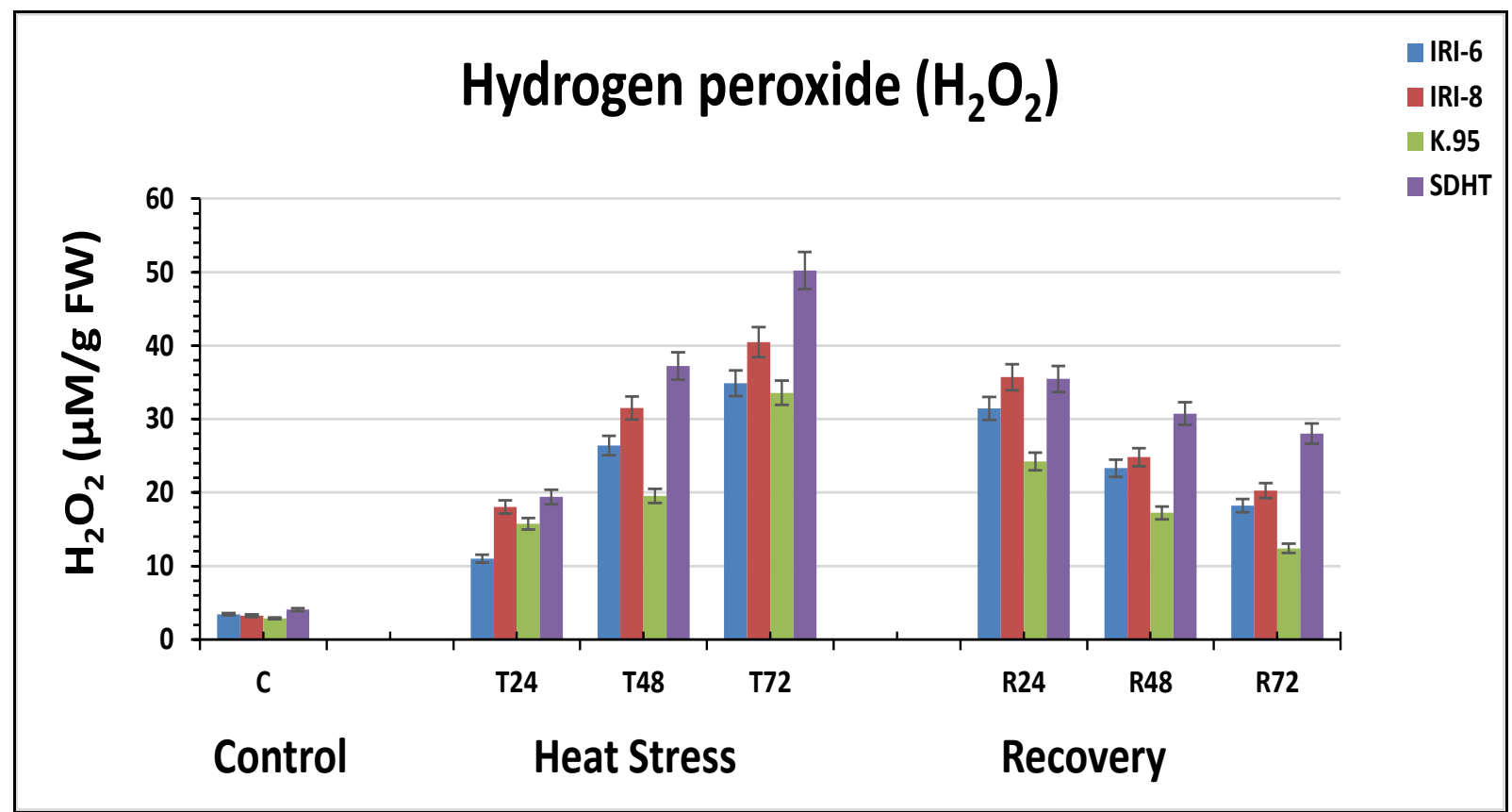

Figure 1. Hydrogen peroxide $\left(\mathrm{H}_{2} \mathrm{O}_{2}\right)$ content of four rice cultivars, IR-6, IR-8, K-95 and Sada Hayat subjected to control (C), heat stress (T24, T48 and T72) and recovery (R24, $R 48$ and $R 72$ ) conditions at seedling stage

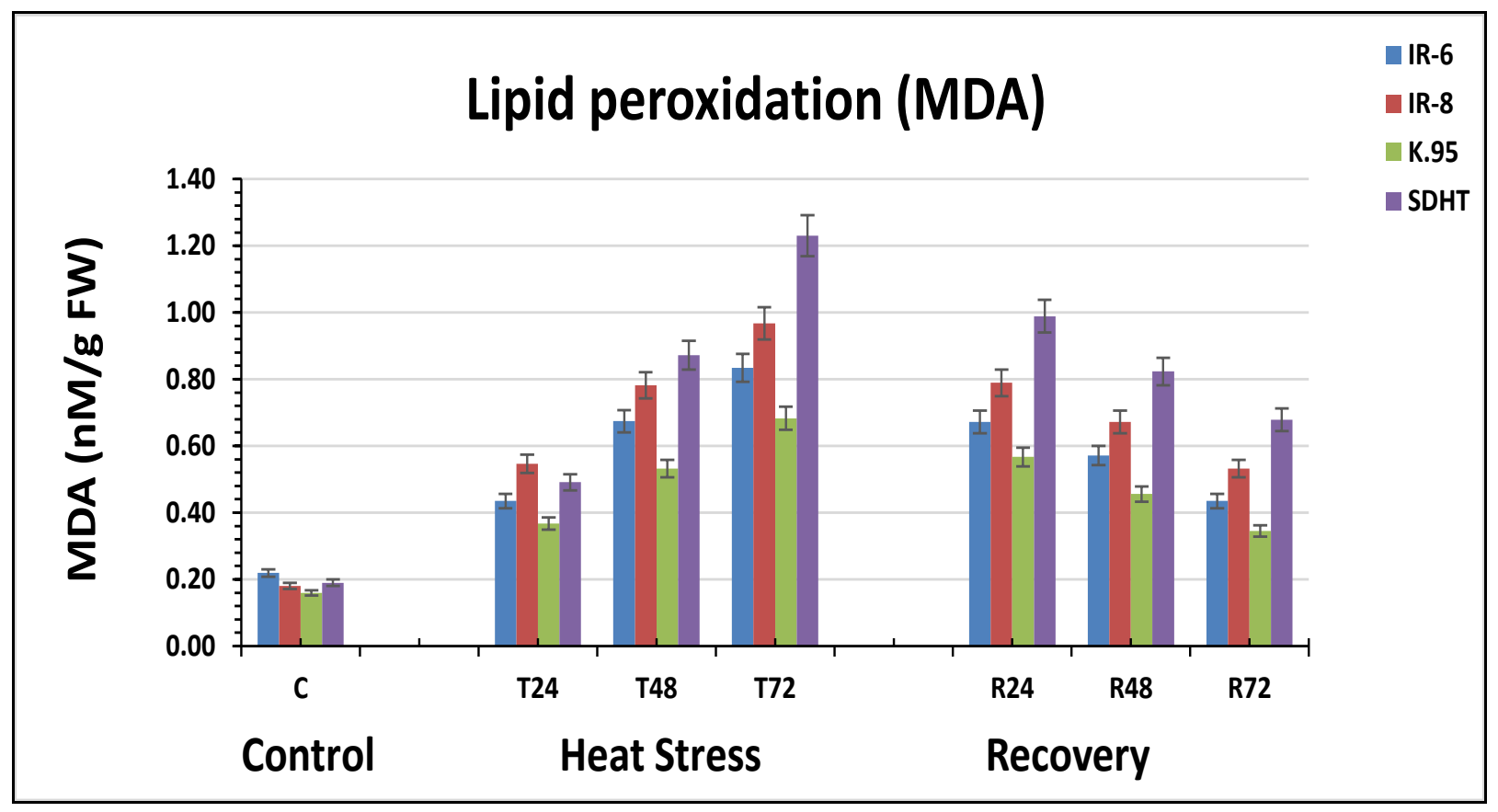

Figure 2. Content of melondialdehyde (MDA) in four rice cultivars, IR-6, IR-8, K-95 and Sada Hayat under control (C), heat stress (T24, T48 and T72) and recovery (R24, R48 and R72) conditions 


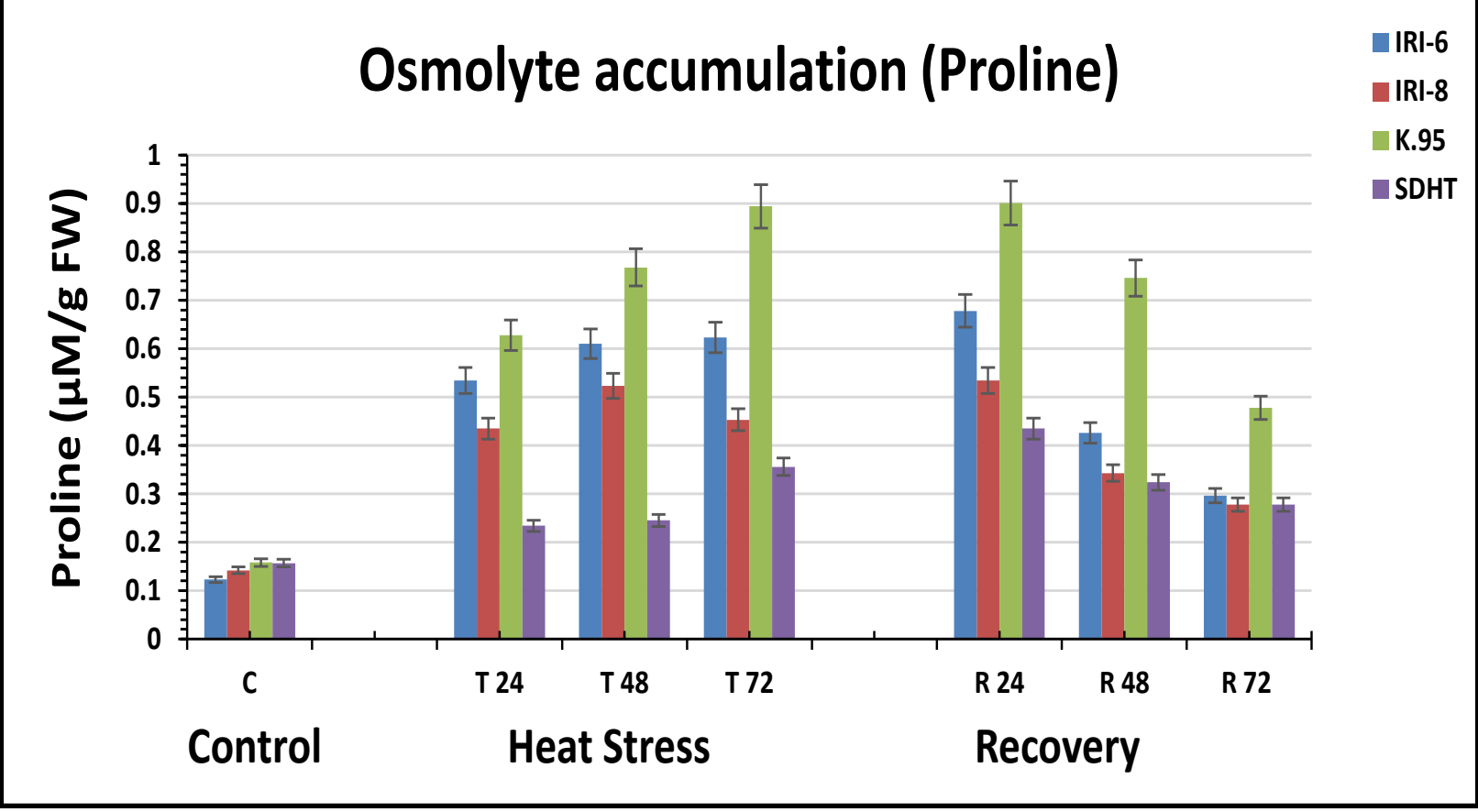

Figure 3. Accumulation of osmolyte (proline) in four rice cultivars, IR-6, IR-8, K-95 and Sada Hayat subjected with control (C), heat stress (T24, T48 and T72) and recovery (R24, R48 and R72) treatments at early growth stag

\section{Antioxidant system}

Elevated temperature from threshold can cause oxidative damage due to over production of ROS. Thus, plant cells need different mechanisms for quenching of excess free radicles and keep them in balance condition. To elucidate differences in response of antioxidant system of rice cultivars under heat stress, response of ascorbate peroxidase (APX) and catalase (CAT) were observed in heat treated seedlings of rice cultivars.

Catalase (CAT) enzyme is the principal component of antioxidant defence system responsible if scavenging harmful oxygen species specifically $\mathrm{H}_{2} \mathrm{O}_{2}$, therefore, better activity of CAT play important role in reducing heat stress-induced damages [39]. In this investigation, catalase enzyme showed markedly declined activities under stress condition and recovered upon recovery treatments (Figure 4) suggesting that thermal stress has negative effect on CAT activity. The increment in CAT enzyme activity under stress conditions can be explained by the very low affinity of this enzyme for $\mathrm{H}_{2} \mathrm{O}_{2}$, as it becomes active at relatively high $\mathrm{H}_{2} \mathrm{O}_{2}$ concentrations [40]. It is also suggested that higher CAT concentrations may have removed the superoxide $\left(\mathrm{O} 2^{-}\right)$radicals induced by heat stress [30].

High temperature treatment showed insignificant rise in ascorbate peroxidase (APX) activity in all cultivars and Sada Hayat seedlings showed significantly $(p \leq$ 0.05) declined pattern of APX (Figure 5). According to Celikkol [41], APX enzymes experience oxidation and inactivation upon application of stress treatments leading enhanced accumulation of ROS in cells. Previously decline in activity of APX enzyme has been reported under water stress condition [42].

The findings of the investigation of various biochemical and physiological attributes manifested that under high temperature stress rice cultivars shared common 
characteristics, however, cultivar K-95 appeared to be biochemically as well as physiologically effective and strong mechanism, hence, less effected. CAT enzyme activity might have played important and protective role in K-95 and IR-6 which showed thermotolerance under heat stress condition. Despite the over production of $\mathrm{H}_{2} \mathrm{O}_{2}$ content in K-95 shoots under heat stress conditions, lipid peroxidation (MDA) content did not increase, indicating cell membrane integrity due to lower oxidative damages. In all cultivars, CAT enzyme seems to play key role in maintaining $\mathrm{H}_{2} \mathrm{O}_{2}$ concentration at normal level, inhibiting chain reaction of reactive oxygen species that may lead to cell death. In K-95 despite the activity of catalase alone, decline in APX activity seems to cause an increment in level of $\mathrm{H}_{2} \mathrm{O}_{2}$ concentration, however, in Sada Hayat and IR-8 slight uplift in activity of APX enzyme together with CAT activity achieved the fine modulation of $\mathrm{H}_{2} \mathrm{O}_{2}$ content. K-95 showed increment in content of hydrogen peroxide at lesser magnitudes of high temperature stress where ascorbate and catalase had insignificant activity; however, MDA amounts were stable as compared to the controls. According to our results, two cultivars (K-95 and IR-6) were thermotolerant, whereas K-95 appeared to be less affected biochemically and physiologically, rendering K-95 thermotolerant followed by IR-6 while Sada Hayat and IR-8 were thermo-susceptible. The rice cultivar Sada Hayat had more damages as compared to IR-8.

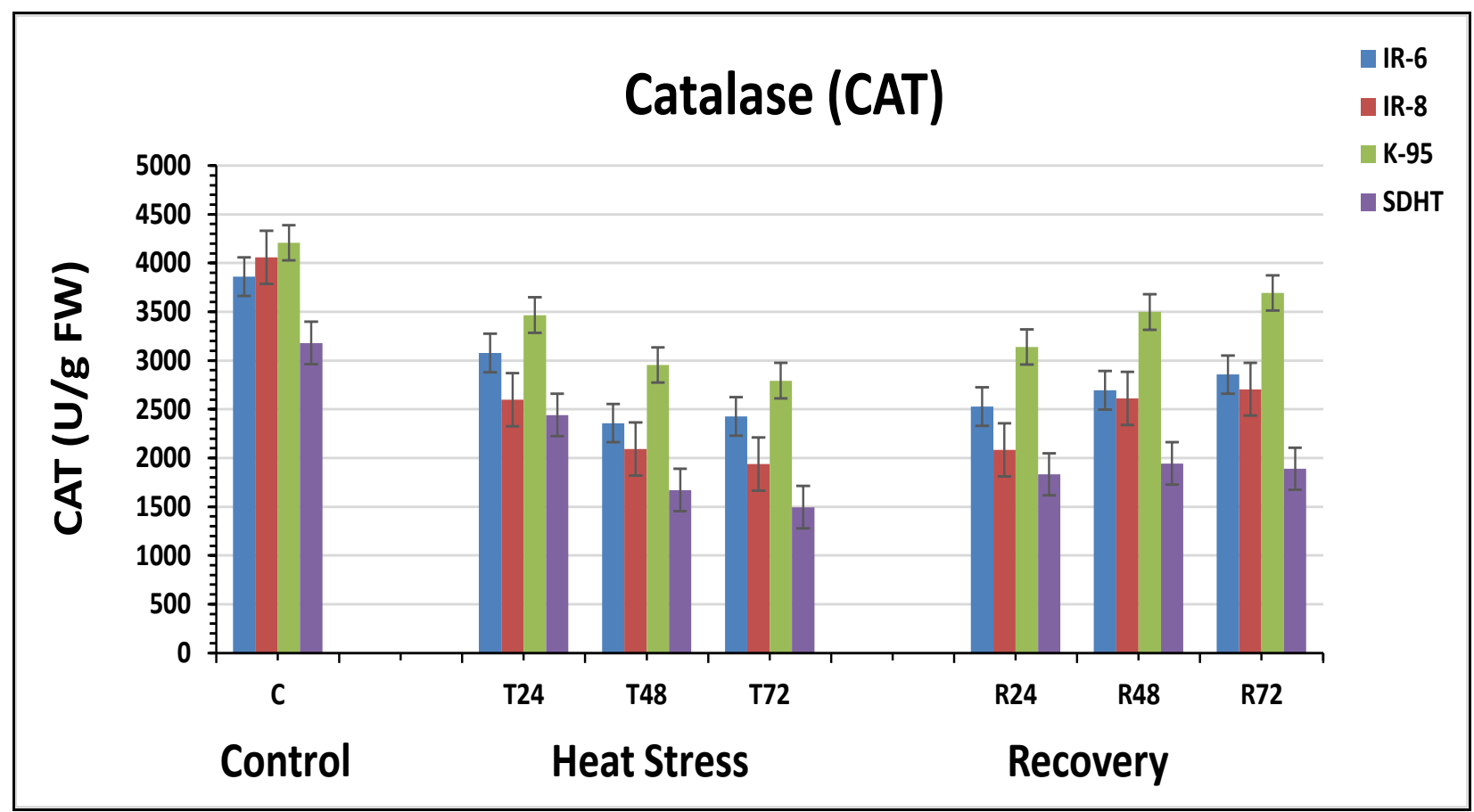

Figure 4. Catalase (CAT) enzyme activity in four rice cultivars, IR-6, IR-8, K-95 and Sada Hayat at seedling stage grown under control (C), heat stress (T24, T48 and T72) and recovery ( $R 24, R 48$ and $R 72)$ conditions. 


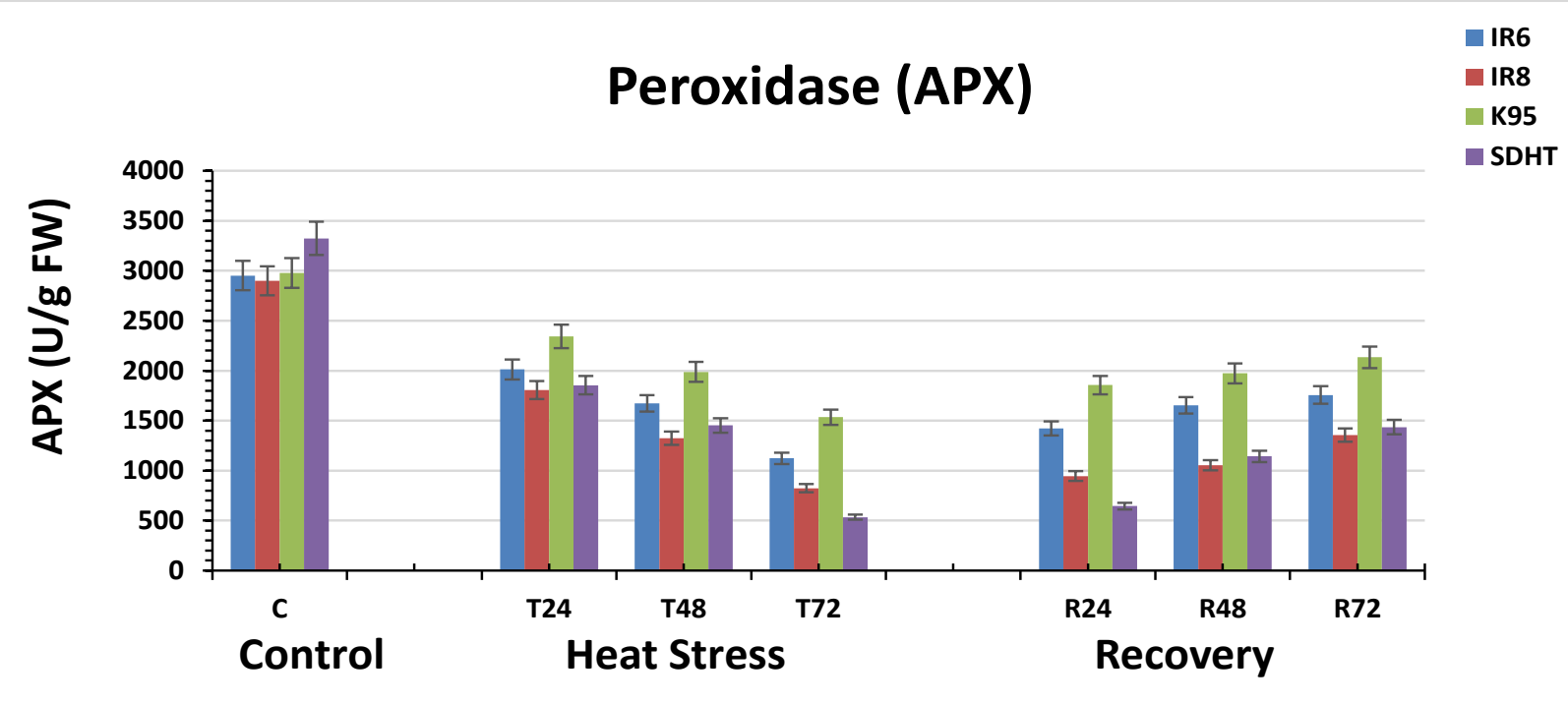

Figure 5. Effect of heat stress on Ascorbate peroxidase (APX) enzyme activity in four rice cultivars, IR-6, IR-8, K-95 and Sada Hayat subjected with control (C), heat stress (T24, $T 48$ and $T 72)$ and recovery $(R 24, R 48$ and $R 72)$ conditions

\section{Conclusion}

From the findings, it is concluded that rice cultivar "K-95" comparatively performed better under heat stress condition showing thermotolerant ability with minimal oxidative damages and improved antioxidant system and maximum accumulation of osmolyte (Proline) followed by "IR-6," while "Sada Hayat" showed heat susceptibility with maximum oxidative damages and compromised antioxidant system having week capability of osmolyte accumulation for maintaining cell homeostasis under harsh condition.

\section{Author's contributions}

Conceived and designed the experiments: $S$ Galani, Performed and analyzed the data and paper wrote: MK Ali, Paper Writing: HU Rehman, Contributed reagents /materials/ analysis tools: A Azhar.

\section{References}

1. Makbul S, Saruhan GN, Durmuş N \& Guven S (2011). Changes in anatomical and physiological parameters of soybean under drought stress. Turk $J$ Bot 35: 369-377.

2. Bray EA, Bailey-Serres J \& Weretilnyk E (2000). Responses to abiotic stresses.
In: Gruissem W, Buchannan B, Jones

R, eds. Biochemistry and Molecular Biology of Plants. Rockville pp. 11581249.

3. Gunderson CA, Norby RJ \& Wullschleger SD (2000). Acclimation of photosynthesis and respiration to simulated climatic warming in northern and southern populations of Acer saccharum: laboratory and field evidence. Tree Physiology 20: 87-96.

4. Peng S, Huang J, Sheehy JE, Laza RC, Visperas RM, Zhong X, Centeno GS, Khush GS \& Cassman KG (2004). Rice yields decline with higher night temperature from global warming. Proc Natl Acad Sci USA 101: 9971-9975.

5. Mittler R, Vanderauwera S, Gollery M \& Van Breusegem F (2004). Reactive oxygen gene network of plants. Trends Plant Sci 9: 490-498.

6. Baysal Furtana G \& Tipırdamaz R (2010). Physiological and antioxidant response of three cultivars of cucumber (Cucumis sativus L.) to salinity. Turk J Biol 34: 287-296.

7. Bowler C, Montagu MV \& Inze D (1992). Superoxide dismutase and stress 
tolerance. Annu Rev Plant Phys 43: 83116.

8. Celikkol Akcay U, Ercan O, Kavas M, Yildiz L, Yilmaz C, Oktem HA \& Yucel M (2010). Drought-induced oxidative damage and antioxidant responses in peanut (Arachis hypogaea L.) seedlings. Plant Growth Regul 61: 21-28.

9. Halliwell B (1987). Oxidative damage, lipid peroxidation and antioxidant protection in chloroplasts. Chem Phys Lipids 44: 327-340.

10. Rabinowitch HD \& Fridovic I (1983). Superoxide radical, superoxide dismutase and oxygen toxicity in plants. Photochem Photobiol 188: 206-213.

11. Fridovich I (1986). Biological effects of superoxide radical. Arch Biochem Biophys 247: 1-11.

12. Schulze ED (1986). Carbon dioxide and water vapor exchange in response to drought in the atmosphere and in the soil. Ann Rev Plant Physio 37: $247-$ 274.

13. Hare PD \& Cress WA (1997). Metabolic implications of stress-induced proline accumulation in plants. Plant Growth Regul 21: 79-102.

14. Ain-Lhout F, Zunzunegui FA, Barradas MCD, Tirado R, Clavijio A \& Garcia NF (2001). Comparison of proline accumulation in two Mediterranean shrubs subjected to natural and experimental water deficit. Plant Soil 230: 175-183.

15. Kim TH, Lee BR, Jung WJ, Kim KY, Avice JC \& Qurry A (2004). De novo protein synthesis in relation to ammonia and proline accumulation in water stressed white clover. Funct Plant Biol 31: 847-855.

16. Lee BR, Jin YL, Avice JC, Cliquet JB, Qurry A \& Kim TH (2009). Increased proline loading to phloem and its effects on nitrogen uptake and assimilation in water-stressed white clover (Trifolium repens). New Phytol 182: 654-663.

17. Smirnoff N \& Cumbes QJ (1989). Hydroxyl radical scavenging activity of compatible solutes. Phytochemistry 28: 1057-1060.

18. Matysik J, Alia, Bhalu B \& Mohanty P (2002). Molecular mechanisms of quenching of reactive oxygen species by proline under stress in plants. Curr Sci India 82: 525-532.

19. Demiralay M, Sağlam A \& Kadıŏlu A (2013). Salicylic acid delays leaf rolling by inducing antioxidant enzymes and modulating osmoprotectant content in Ctenanthe setosa under osmotic stress. Turk $J$ Biol 37: 49-59.

20. Hoagland DR \& Arnon DI (1950). The water-culture method for growing plants without soil. Calif Aes Bull 347: $1-32$.

21. Jessup W, Dean R \& Gebicki J (1994). Iodometric determination of hydroperoxides in lipids and proteins. Methods Enzymol 233: 289-303.

22. Ohkawa H, Ohishi N \& Yagi Y (1979). Assay of lipid peroxides in animal tissue by thiobarbituric acid reaction. Anal Biochem 95: 351-358.

23. Bates LS, Waldren RP \& Teare ID (1973). Rapid determination of free proline for water-stress studies. Plant Soil 39: 205-207.

24. Bradford MM (1976). A rapid and sensitive method for the quantification of microgram quantities of protein utilizing the principle of protein-dye binding. Anal Biochem 72: 248-254.

25. Wang SY, Jiao H \& Faust M (1991). Changes in ascorbate, glutathione and related enzyme activities during thiodiazuron induced bud break of apple. Plant Physiol 82: 231-236. 
26. Chance B \& Maehly AC (1995). Assay of catalases and peroxidases. Method Enzymol 2: 764-817.

27. Nayar H \& Kaushal SK (2002). Chilling induced oxidative stress in germinating wheat grains as affected by water stress and calcium. Biol Plant 45: 601604.

28. Yazici I, Turkan I, Sekmen AH \& Demiral T (2007). Salinity tolerance of purslane (Portulaca oleracea L.) is achieved by enhanced antioxidative system, lower level of lipid peroxidation and proline accumulation. Environ Exp Bot 61: 49-57.

29. Marnett LJ (1999). Lipid peroxidationDNA damage by malondialdehyde. Mutat Res 424: 83-95.

30. Sairam RK, Srivastava GC \& Saxena DC (2000). Increased antioxidant activity under elevated temperatures: a mechanism of heat stress tolerance in wheat genotypes. Biol Plant 43: 245251.

31. Ashraf M \& Foolad MR (2007). Roles of glycine betaine and proline in improving plant abiotic stress resistance. Environ Exp Bot 59: 206216.

32. Reddy AR, Chaitanya KV \& Vivekanandan M (2004). Drought induced responses of photosynthesis and antioxidant metabolism in higher plants. J Plant Physiol 161: 11891202.

33. Behnamnia M, Kalantari KM \& Ziaie J (2009). The effects of brassinosteroid on the induction of biochemical changes in Lycopersicon esculentum under drought stress. Turk J Bot 33: 417-428.

34. Malik AA, Li WG, Lou LN, Weng JH \& Chen JF (2010). Biochemical/ physiological characterization and evaluation of in vitro salt tolerance in cucumber. Afr J Biotechnol 9: 32843292.

35. Sun WJ, Nie YX, Gao Y, Dai AH \& Bai JG (2011). Exogenous cinnamic acid regulates antioxidant enzyme activity and reduces lipid peroxidation in drought-stressed cucumber leaves. Acta Physiol Plant 34: 641-655.

36. Baloğlu MC, Kavas M, Aydın G, Oktem HA \& Yucel M (2012). Antioxidative and physiological responses of two sunflowers (Helianthus annuus) cultivars under PEG-mediated drought stress. Turk J Bot 36: 707-714.

37. Arikan Ceylan H, Turkan I \& Sekmen AH (2012). Effect of coronatine on antioxidant enzyme response of chickpea roots to combination of PEGinduced osmotic stress and heat stress. J Plant Growth Regul 32: 72-82.

38. Maxwell K \& Johnson GN (2000). Chlorophyll fluorescence-a practical guide. J Exp Bol 51: 659-668.

39. Pereira GJG, Molina SMG, Lea PJ \& Azevedo RA (2002). Activity of antioxidant enzymes in response to cadmium in Crotalaria juncea. Plant Soil 239: 123-132.

40. Gechev TS, Van Breusegem F, Stone JM, Denev I \& Laloi C (2006). Reactive oxygen species as signals that modulate plant stress responses and programmed cell death. Bio Essays 28: 1091- 1101.

41. Celik O \& Atak C (2012). The effect of salt stress on antioxidative enzymes and proline content of two Turkish tobacco varieties. Turk J Biol 36: 339356.

42. Mohammad khani N \& Heidari R (2007). Effects of drought stress on protective enzyme activities and lipid peroxidation in two maize cultivars. Pak J Biol Sci 10: 3835-3840. 